University of Nebraska - Lincoln

DigitalCommons@University of Nebraska - Lincoln

1993

\title{
The Conservation Reserve Program and Grassland Birds
}

Douglas H. Johnson

Northern Prairie Wildlife Research Center, Douglas_H_Johnson@usgs.gov

Michael D. Schwartz

USGS Northern Prairie Wildlife Research Center

Follow this and additional works at: https://digitalcommons.unl.edu/usgsnpwrc

Part of the Other International and Area Studies Commons

Johnson, Douglas H. and Schwartz, Michael D., "The Conservation Reserve Program and Grassland Birds" (1993). USGS Northern Prairie Wildlife Research Center. 194.

https://digitalcommons.unl.edu/usgsnpwrc/194

This Article is brought to you for free and open access by the US Geological Survey at DigitalCommons@University of Nebraska - Lincoln. It has been accepted for inclusion in USGS Northern Prairie Wildlife Research Center by an authorized administrator of DigitalCommons@University of Nebraska - Lincoln. 


\section{The Conservation Reserve Program and Grassland Birds}

\author{
DOUGLAS H. JOHNSON \\ MICHAEL D. SCHWARTZ
}

U.S. Fish and Wildlife Service

Northern Prairie Wildlife Research Center

Jamestown, ND 58401, U.S.A.

\section{Introduction}

Several bird species that breed in the temperate grasslands of North America, many of which winter in the Neotropics, declined in abundance during the past quarter century. The Lark Bunting (see Table 1 for scientific names) and Grasshopper Sparrow, as examples, declined by about half during that period, as indexed by the U.S. Fish and Wildlife Service's Breeding Bird Survey. Populations of other grassland species have also diminished steadily, if not as spectacularly.

Why so many species declined is not known, but continued conversion of perennial grassland to annually tilled cropland is a suspected cause. A test of this possibility is offered by the Conservation Reserve Program, a program of the United States Department of Agriculture that caused the reversion of millions of hectares of marginal cropland to perennial grassland. Under this Program, landowners are paid to plant perennial vegetation on certain eroding or highly erodible fields. They receive annual payments during the 10 years of the contract. Although the primary objectives of the Program involved reduction of crop surpluses and protection of soil from erosion, wildlife habitat was listed as a secondary objective.

We evaluated the use by breeding birds of selected Program fields in eastern Montana, North Dakota, South Dakota, and western Minnesota. These four states have about four million hectares of land enrolled in the Program.

\section{Study Areas and Methods}

We selected nine counties for sampling in order to have one county representing each major geological land- form within each state. In each county, we selected fields with a broad range of sizes and practices.

We surveyed fields for breeding birds according to the procedures of Stewart and Kantrud (1972), which allow a fairly rapid assessment of the breeding bird community of a field. Each field was searched once each year by one or two observers on foot. All indicated breeding pairs were tallied, based on vocalizing males, females (for Brown-headed Cowbirds), pairs, or a nest. Surveys were made between dawn and midafternoon, avoiding precipitation or strong winds. Surveys were conducted during 22 May to 2 July 1990 and 28 May to 29 June 1991.

We obtained population trends for birds from Breeding Bird Survey (Robbins et al. 1986) results during 1966-1990 for the Central Region, roughly between the Rocky Mountains and the Mississippi River, and for the continent north of Mexico. Trends were based on methods described by Geissler and Sauer (1990).

In 1990 , we counted birds on 240 fields in the nine counties, for a total area of 4654 ha. In 1991 we surveyed 335 fields totaling 6181 ha; 190 of these fields, involving $3662 \mathrm{ha}$, had also been included in 1990. For the two years, field size ranged from 0.5 to $72.7 \mathrm{ha}$, with a median of 14.4 ha. Grasses and legumes were the most common plants on Conservation Reserve Program fields, but variation was considerable from county to county and among fields.

\section{Results}

We recorded 73 species of birds on the Conservation Reserve Program fields. Total densities (indicated pairs 
Table 1. Densities of breeding birds (indicated pairs/100 ha) in cropland and in Conservation Reserve Program fields, and trends in abundance estimated from Breeding Bird Surveys.

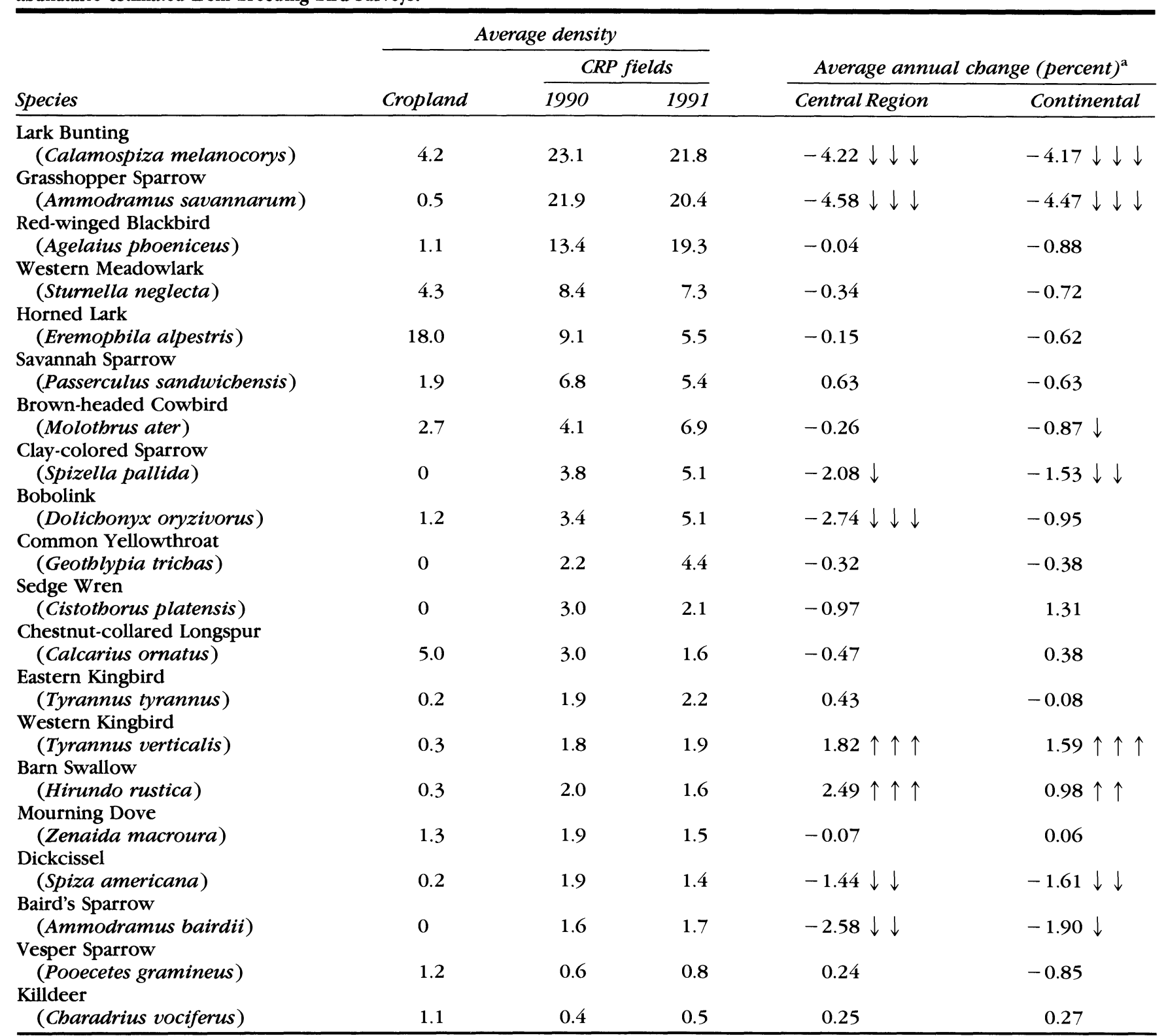

a $\downarrow$ decreasing $(\uparrow$ increasing) at $\mathrm{P}<0.10 ; \downarrow \downarrow(\uparrow \uparrow)$ at $\mathrm{P}<0.05 ; \downarrow \downarrow \downarrow(\uparrow \uparrow \uparrow)$ at $\mathrm{P}<0.01$.

per 100 ha) were 123.5 in 1990 and 123.6 in 1991. Overall, the Lark Bunting was the most abundant bird in Program fields, although it was absent or rare in counties in the Drift Prairie and Black Prairie (Table 2). The Grasshopper Sparrow was the next most common species. The Red-winged Blackbird, third in average abundance, was uncommon in the more arid habitats of Montana and Butte County, South Dakota. The Western Meadowlark and Horned Lark, ranked fourth and fifth, showed patterns of abundance decreasing from west to east. Among the other species common in the fields, the Eastern Kingbird, Barn Swallow, and Mourning Dove occurred fairly regularly with average densities not vary- ing markedly by county (Table 2 ). The Western Kingbird was most common in the Missouri Coteau and Drift Prairie; it was uncommon in the Black Prairie. The remaining species were far more variable, having high densities in some counties and being absent from others.

For a comparison with cropland bird populations, we examined the original data from the Stewart and Kantrud (1972) survey, which provided information on 194 cropland fields totaling 4400 ha. Only the Horned Lark occurred in appreciably higher densities in cropland than in Conservation Reserve Program land, and the Chestnut-collared Longspur, Vesper Sparrow, and Kill- 
Table 2. Average density of breeding birds (indicated pairs/100 ha) in Conservation Reserve Program fields, by county, 1990-1991 average.

\begin{tabular}{|c|c|c|c|c|c|c|c|c|c|c|}
\hline \multirow[b]{2}{*}{ Species } & \multicolumn{3}{|c|}{ Great Plains Roughlands } & \multicolumn{3}{|c|}{ Missouri Coteau } & \multicolumn{2}{|c|}{ Drift Prairie } & \multirow{2}{*}{$\begin{array}{c}\text { Black Prairie } \\
\text { Grant } \\
M N\end{array}$} & \multirow[b]{2}{*}{ Average } \\
\hline & $\begin{array}{c}\text { Fallon } \\
\text { MT }\end{array}$ & $\begin{array}{c}\text { Butte } \\
\text { SD }\end{array}$ & $\begin{array}{c}\text { Hettinger } \\
N D\end{array}$ & $\begin{array}{c}\text { Sheridan } \\
\text { MT }\end{array}$ & $\begin{array}{c}\text { Kidder } \\
N D\end{array}$ & $\begin{array}{c}\text { McPherson } \\
S D\end{array}$ & $\begin{array}{c}E d d y \\
N D\end{array}$ & $\begin{array}{c}\text { Day } \\
\text { SD }\end{array}$ & & \\
\hline Lark Bunting & 22.1 & 34.3 & 53.3 & 56.0 & 9.6 & 18.6 & 0.1 & 0 & 0 & 22.4 \\
\hline Grasshopper Sparrow & 11.8 & 9.9 & 27.1 & 22.8 & 18.4 & 37.5 & 34.3 & 17.8 & 9.4 & 21.2 \\
\hline Red-winged Blackbird & 0.8 & 2.1 & 22.1 & 4.3 & 25.4 & 25.8 & 18.7 & 32.6 & 18.7 & 16.4 \\
\hline Western Meadowlark & 12.8 & 13.2 & 9.0 & 7.4 & 6.8 & 8.2 & 6.0 & 3.3 & 1.3 & 7.8 \\
\hline Horned Lark & 10.1 & 20.0 & 6.7 & 15.2 & 3.4 & 4.8 & 2.4 & 0.5 & 0.1 & 7.3 \\
\hline Savannah Sparrow & 0.1 & 0.4 & 9.2 & 4.6 & 5.7 & 2.8 & 8.0 & 14.1 & 11.9 & 6.1 \\
\hline Brown-headed Cowbird & 1.7 & 0.6 & 8.1 & 11.8 & 5.3 & 8.3 & 6.1 & 5.0 & 1.2 & 5.5 \\
\hline Clay-colored Sparrow & 0 & 0 & 0.5 & 6.4 & 2.2 & 2.1 & 12.0 & 12.4 & 6.7 & 4.5 \\
\hline Bobolink & 0 & 0.1 & 5.1 & 1.5 & 2.5 & 1.6 & 5.5 & 9.7 & 15.6 & 4.2 \\
\hline Common Yellowthroat & 0 & 0 & 0.4 & 0.2 & 1.9 & 1.8 & 3.3 & 12.6 & 13.6 & 3.3 \\
\hline Sedge Wren & 0 & 0 & 0 & 0 & 0.2 & 0 & 0.7 & 9.6 & 17.0 & 2.6 \\
\hline Chestnut-collared Longspur & 0 & 1.1 & 3.1 & 9.8 & 2.5 & 3.8 & 0 & 0.1 & 0 & 2.3 \\
\hline Eastern Kingbird & 1.0 & 0.8 & 1.5 & 1.9 & 3.1 & 2.5 & 3.5 & 2.4 & 1.4 & 2.1 \\
\hline Western Kingbird & 0.6 & 0.4 & 1.1 & 1.4 & 4.6 & 4.4 & 1.7 & 1.7 & 0.1 & 1.8 \\
\hline Barn Swallow & 1.7 & 1.4 & 1.0 & 0.7 & 1.4 & 1.9 & 1.9 & 3.0 & 4.0 & 1.8 \\
\hline Mourning Dove & 2.0 & 1.0 & 2.8 & 0.6 & 1.6 & 4.0 & 1.8 & 0.7 & 0.5 & 1.7 \\
\hline Dickcissel & 0 & 0 & 0 & 0 & 0.4 & 1.3 & 0.3 & 10.7 & 4.1 & 1.6 \\
\hline Baird's Sparrow & 0.5 & 1.1 & 0.1 & 9.2 & 1.3 & 1.2 & 0.7 & 0.5 & 0 & 1.6 \\
\hline
\end{tabular}

${ }^{a}$ Weighted by area surveyed within each county.

deer were slightly more common in cropland (Table 1 ). In contrast, densities of the other 16 species listed were seven times greater (the median) in Program fields than in cropland.

We examined the population trends of these species, using the 1966-1990 data from Breeding Bird Surveys. Of the four species that occurred in higher densities in cropland than in Conservation Reserve Program fields, none had a significant $(P<0.10)$ upward or downward trend (Table 1). Six of the species less common in cropland than Program fields had significant downward trends. The two most common species in Program fields, the Lark Bunting and Grasshopper Sparrow, declined by more than 4 percent per year during 19661990 , both in the Central Region and continentally (Table 1). The Clay-colored Sparrow also declined significantly in the Central Region and continentally. The Bobolink had been declining at 2.7 percent per year in the Central Region, and the Dickcissel at about 1.5 percent per year. Baird's Sparrow, a prairie species with a restricted range, had been declining at 2 percent per year.

\section{Discussion}

Several prairie species that seriously declined in abundance during 1966-1990 were common in Conservation Reserve Program fields. These species presumably diminished because of the conversion of perennial grassland habitat to annually tilled cropland, although exact causes are unclear. Our results, like those of King
(1991) for southeastern Nebraska, indicate that the Conservation Reserve Program offers breeding habitat for several of these species and, if continued, may have the potential to reverse their downward trends.

Although more research on habitats provided by the Conservation Reserve Program in the northern Great Plains can and should be carried out, early results indicate the tremendous value of restored grasslands to a host of breeding prairie birds. The Program provided for 10-year leases, which will begin to expire in 1996. At that time, many farmers will likely return their Program fields to cultivation, even though those areas may not be needed to meet demands for crop production. It would be wise conservation-of soil, water, and bird resources-to continue the Conservation Reserve Program in some form.

\section{Acknowledgments}

We appreciate the cooperation of the landowners who allowed us access to their fields, to the state Agricultural Stabilization and Conservation Service directors, and to the executive directors and staffs of county ASCS offices who provided us with information. We thank K. L. Richardson and J. M. Steiner for collecting data. H. A. Kantrud furnished the original data gathered by Stewart and Kantrud (1972). S. Droege and J. R. Sauer of the U.S. Fish and Wildlife Service supplied information from the Breeding Bird Survey. L. B. Best, H. A. Kantrud, R. E. Kirby, R. R. Koford, P. J. Pietz, and J. T. Price commented on earlier drafts of this report. 


\section{Literature Cited}

Geissler, P. H., and J. R. Sauer. 1990. Topics in route-regression analysis. Pages 54-57 in J. R. Sauer and S. Droege, editors. Survey designs and statistical methods for the estimation of avian population trends. U.S. Fish and Wildlife Service, Biological Report 90(1).

King, J.W. 1991. Effects of the Conservation Reserve Program on selected wildlife populations in southeast Nebraska. Un- published M.S. Thesis. University of Nebraska, Lincoln, Nebraska. $39 \mathrm{pp}$.

Robbins, C. S., D. Bystrak, and P. H. Geissler. 1986. The breeding bird survey: Its first fifteen years, 1965-1979. U.S. Fish and Wildlife Service Resource Publication 157. 196 pp.

Stewart, R. E., and H. A. Kantrud. 1972. Population estimates of breeding birds in North Dakota. Auk 89:766-788.

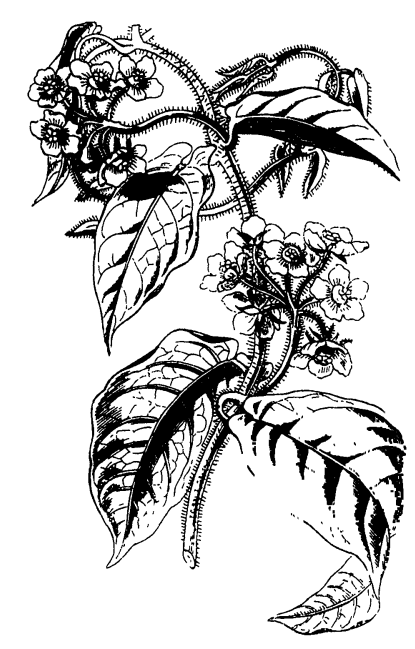

